\section{Medicinal plants at the Sítio do Gois, Apodi, Rio Grande do Norte State, Brazil}

\section{Renan da C. Paulino, ${ }^{1}$ Gabrielly P. de S. A. Henriques, ${ }^{1}$ Olga N. S. Moura, ${ }^{1}$ Maria de Fatima B. Coelho,,", Rodrigo A. B. Azevedo ${ }^{2}$}

${ }^{1}$ Departamento de Ciências Vegetais, Universidade Federal Rural do Semi Árido, Brazil,

${ }^{2}$ Setor de Desenvolvimento Rural,Universidade da Integração Internacional da Lusofonia Afro Brasileira, Brazil.

\begin{abstract}
Rural communities have accumulated knowledge about survival techniques in the midst of difficulties, such as ecological, economic or social, and one of the transformation spaces and extraction of resources to these communities is the natural vegetation and homegarden. The aim of this study was to list medicinal plants and characterize the use of these plants at the Sítio do Gois, Apodi-RN, Brazil. Openinterview, semi-structured and guided tours by local experts (field guide person, foresters, herb doctors, healers, farmers, housewives) were realized. Medicinal plants are distributed in 34 families, 46 genera and 52 species. The family with the greatest number of individuals was Lamiaceae (seven species). The species most mentioned were Amburana cearensis (77\%) followed by $69 \%$ de citation of Myracrodruon urundeuva, Sideroxylon obtusifolium, Ximenia americana. Informants are aware of specific uses of native medicinal plants of the caatinga and homegardens. The most common preparations are teas and syrups, used part is the leaf and stem bark and great number of citations for disorders of the digestive and respiratory systems. The most important species with greater use agreement were $A$. cearensis M. urundeuva, S. obtusifolium and X. americana they deserve pharmacological studies and validation.
\end{abstract}

Revista Brasileira de Farmacognosia Brazilian Journal of Pharmacognosy 22(1): 29-39, Jan./Feb. 2012

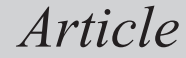

Received 31 Mar 2011

Accepted 14 Jul 2011

Available online 16 Nov 201

Keywords:

Dry climate northeastern Brazil

Rio Grande do Norte medicinal plants

ISSN 0102-695X http://dx.doi.org/10.1590/S0102$695 \times 2011005000203$

\section{Introduction}

Every human society in interaction with the environment can generate and collect essential information for their survival with minimal environmental damage (Albuquerque \& Andrade 2002a; Amorozo, 1996).

The knowledge generated by rural communities on the environment that surrounds them has been lost. It is argued that we must rescue it, before it is too late, because this precious knowledge represents centuries or even millennia of empirical knowledge accumulation (Amorozo, 1996). However, it is urgently necessary to record the useful species for the development of new drugs, but at the same time evaluate their degree of threat and develop strategies for their conservation, thereby contributing to the protection of biodiversity (Bermúdez et al., 2005).

The approach to the study of medicinal plants from their use by traditional communities can save time and money with useful information in chemical, pharmacological and agronomic studies, because it is started from a previously generated knowledge (Amorozo, 1996). The first step to produce a new medicine would be the research and documentation of traditional knowledge (Bermudez et al., 2005, Maciel et al., 2002) which is denominated ethno-directed method (Albuquerque \& Hanazaki, 2006).

In the semiarid region of northeastern Brazil there have been several studies conducted on the knowledge of use of medicinal plant species. Emperaire \& Pinton (1986), Albuquerque et al., (2005b), Albuquerque et al., (2007), Florentino et al., (2007), Duque-Brazil et al., (2008), Pessoa \& Cartagena (2010) and Oliveira et al., (2010a,b) studies showed a significant richness and diversity of medicinal species kept in homegardens. In Rio Grande do Norte State, there are a few investigations about medicinal plants in homegardens (Mosca \& Loiola 2009, Guerra et al., 2010).

The aim of this study was to list medicinal plants and characterize the use of these plants in a small village Sítio do Góis, city of Apodi, Rio Grande do Norte, Brazil. 


\section{Material and Methods}

Study area

The study was conduct at Sítio do Gois located in Apodi municipality of the State of Rio Grande do Norte, Brazil in Southern West Potiguar microregion of Apodi Plateau (S5 $25^{\prime} 28^{\prime \prime}$ and W37 $\left.47^{\prime} 25^{\prime \prime}\right), 334 \mathrm{~km}$ far from the Capital, Natal (MME, 2005). The climate is hot and semiarid; it is BSwh' type according to Koppen's classification, with average annual temperature of 28.1 ${ }^{\circ} \mathrm{C}$, annual relative humidity of $68 \%$ and 2700 hours of sunshine and an average annual rainfall of around 833.5 $\mathrm{mm}$ and the rainy season concentrated in the months from March to May (Governo do Rio Grande do Norte, 2010).

The vegetation of the municipality is hyperxerophilous Caatinga of drier vegetation with plenty of cactus plants and lower-sized and scattered samples: Mimosa tenuiflora (Willd.) Poir, Cnidoscolus quercifolius (Müll. Arg.) Pax \& K.Hoffm., Combretum leprosum Mart., Pilosocereus piauhyensis (Gürke) Byles \& G.D. Rowley. and Pilosocereus gounellei (F.A.C. Weber) Byles $\&$ G.D. Rowley. The predominant soils are podzolic soils red-yellow equivalent eutrophic, eutrophic cambisol and rendzina (Governo do Rio Grande do Norte, 2010).

The village consists of sixty families and has a land area of $1774.65 \mathrm{ha}$, there is periodic technical assistance undertaken by NGO. The village survives on dry-land crops such as corn, beans, pumpkin and cotton. It keeps dairy goats that give them an extra income, also bee keeping, another activity explored in the region (Dantas et al., 2007).

The community of Sítio do Gois is very old (1864), housing hundreds of people, mostly related to each other (Dantas et al., 2007). Most population is within the age group of highest yield potential, becoming a facilitator for the development of the settlement. Women stand out in the draft Organic Vegetables in all agro-ecological system and the produced vegetables are sold in open street in Apodi and what is left reverts to his own household consumption. There is no health clinic and the sick people use traditional medicine plants or they request emergency medical care in the cities of Apodi and Mossoro (Fonseca et al., 2008).

There is an elementary school in the community, but students who continue on to middle and high school must move to Apodi city. The community exhibits poorly developed commercial infrastructure and has a public telephone, electricity, and has no public transportation to facilitate the access downtown. There are no paved streets nor a water distribution or sewer system (Fonseca et al., 2008).

\section{Data collection and analysis}

The study was conducted from March 2008 to May 2009. All community members were invited to a meeting where the research objectives were explained. Following this meeting, residents were invited to participate in the study, and if they accepted, they were asked to sign the Free and Informed Consent Term (Azevedo, 2005). The residents indicated those people who are considered by the community as local experts (field guide person, foresters, herb doctors, healers, farmers, housewives).

The interviews were conducted in this group indicated by the community where the informants were selected for the interviews through non-random sampling with a "snowball" method (Albuquerque et al., 2008). Only those individuals over eighteen years old were included in the study and a sample of thirteen people (four women and nine men) representing $23 \%$ of 60 families accepted to participate in the study. The education level of most respondents was among the first four grades of elementary school, and their lives are all linked to agricultural practices.

We made direct observations, open and semistructured interviews with a diary and a recorder (Azevedo \& Coelho, 2002; Albuquerque et al., 2008). The semi-structured interviews began with the following question: "What are the medicinal plants that you know and/or use?" All of the uses of each plant cited were registered, and the informants were also asked which parts of the plant cited were used, its indications, the collection site and the manner of preparing it.

The diseases with medicinal plants were classified according to ICD 10 (International Statistical Classification of Diseases and Related Health Problems, WHO, 2000).

Subsequently, we organized a guided tour in homegardens and the vegetation around and adding to the list of plants by means of visual examination and the collection of plant material for taxonomic identification purposes (Albuquerque et al., 2008). Based on the interviews, a database was built that selected for the purposes of this study only the plants that had medical indications as mentioned by the informants. The plants cited in the interviews were collected and subsequently herborized and identified via comparison with the herbarium material, consultation with experts and specialist literature. The material identified was incorporated into the collection of Herbarium Professor Dardano de Andrade Lima from the Federal Rural University of Semi Arid.

Concordance was calculated as the main uses (CUP) and a correction for citation frequency of species (CUPc) trying to identify the most representative species for the interviewees (Amorozo \& Gely, 1988). The formulas were: CUP = ICUP / ICUE (ICUE number of respondents citing use of the species; ICUP 
- number of respondents citing primary use); CUPc $=$ CUP $\times$ FC $(\mathrm{FC}-$ correction factor $=\mathrm{ICUP} /$ number of informants who cited the species most often cited).

According to plant therapy indications by the informants, it is calculated the Relative Importance of each plant, adapted by Bennett \& Prance (2000); the value is obtained using the formula:

$R I=B S+P H$, where:

$B S=$ Number of body system (genitourinary, gastrointestinal, etc.). It is given by the number of body systems treated by given species (BSS) over the total number of body systems treated by the most versatile species (BSSV).

$$
B S=\frac{B S S}{B S S V}
$$

$P H=$ Number of pharmacological properties (e.g. diuretic, contraceptive etc.). It is given by the number of pharmacological properties attributed to a specific species (PHS) over the total number of properties attributed to the most versatile species (PHSV).

$$
P H=\frac{P H S}{P H S V}
$$

Another index was calculated from ShannonWiener which allows comparisons among the diversity of ethnobotanical knowledge of different communities and in general assists the understanding of their interactions with the environment (Begossi, 1996). The formula used to calculate the diversity index of Shannon-Wiener was:

$$
H^{\prime}=-\underset{i=1}{\sum(\text { pi })\left(\log ^{2} \text { pi }\right)}
$$

where: $H^{\prime}=$ diversity index, $\mathrm{pi}=\mathrm{ni} / \mathrm{N} ; \mathrm{ni}=$ amount of citations per species; $\mathrm{N}=$ total amount of citations.

\section{Results and Discussion}

In this study the medicinal plants were distributed in 34 families, 46 gender and 52 species (Table 1). Families who had higher numbers of individuals were Lamiaceae (seven species), Asteraceae (four species) and Leguminsae-Caesalpininoideae (four species). In many works, the family Lamiaceae is most common. For example, the work done in Jupi by Teixeira \& Melo (2006) eleven species were reported and in the cities of Natal, Coastal region and Santa Cruz, Mosca \& Loiola (2009) recorded seven species in this family. In other studies the family Lamiaceae was well represented: Albertasse (2010), Carnielo et al. (2010), Christo et al. (2010), Almeida et al. (2009), Albuquerque \& Oliveira (2007) and Amorozo (2002). Most species of this family was introduced in Brazil, and they are especially grown in homegardens. They have essential oils responsible for their therapeutic activity and they have high cultural importance.

The species most mentioned were the natives and trees: Amburana cearensis, indicated by $77 \%$ of the interviewees, followed by $69 \%$ de citation of Myracrodruon urundeuva, Sideroxylon obtusifolium, Ximenia americana. A. cearensis was the most frequently cited plant in two other studies conducted in Rio Grande do Norte State (Roque et al., 2010; Silva \& Freire 2010). This species has anti-inflammatory, muscle relaxant and antioxidant (Leal et al., 2009), which explains at least in part the traditional use of $A$. cearensis in the treatment of respiratory diseases where the pathophysiological characteristics include inflammation, oxidative stress and bronchoconstriction.

M. urundeuva is a very common plant in the Northeast region and it is considered one of the best species with anti-inflammatory and healing properties (Souza et al., 2007). Its bark and leaves are widely used to produce dyes, oils and soaps. S. obtusifolium is a very common fruit in the semiarid northeast, and it is also considered of great importance in alternative medicine, bark is often used as a natural astringent and healing (Rodrigues et al., 2007)

A. cearensis, M. urundeuva and S. obtusifolium appear on the Official List of Endangered Species of Brazilian Flora (MMA, 2008). A. cearensis and $M$. urundeuva are also in the red list of threatened species by the World Conservation Union (IUCN, 2007a,b). The versatility of these species in terms of number of uses (timber, fuelwood, fodder, medicine, veterinary medicine, honey) may contribute to higher extraction and the consequent threat of extinction through a process of intense exploration, in a predatory manner, causing the devastation of their natural populations.

Ximenia americana $\mathrm{L}$. is not on the Official List of Endangered Species of Brazilian Flora (MMA, 2008), but the environment where it occurs (coastal plains) is already degraded. Franco \& Barros (2006), in studies of the location and use of species of medicinal herbs in Esperantina Piauí, found that X. americana is a species widely used in fighting infections, injuries and lack of air. Maikai et al. (2010) showed that $X$. americana has antioxidant potential.

It was found that the plants come from homegardens (55\%), natural vegetation $(40 \%)$ and purchased in the market (5\%). Although the Sítio do Gois is located in the Caatinga, cultivated species predominate in homegardens and native species are found in the fragment of caatinga in the vicinity of the village, only $C$. ferrea was found in forest (caatinga) and in homegardens. 
Table 1. Species, used part, kinds of use, status and importance index (IR) of medicinal plants on the Sítio do Góis, Apodi-RN.

\begin{tabular}{|c|c|c|c|c|c|}
\hline Family/Scientific name/Popular name & Used part & Indication and use form & $\begin{array}{c}\text { Status } \\
\text { N/C/PUR }\end{array}$ & Habit & IR \\
\hline \multicolumn{6}{|l|}{ Alliaceae } \\
\hline Alium sativum $\mathrm{L}$., alho & Bulb & $\begin{array}{l}\text { Makes stuffy tea with honey, lemon and eucalyptus it } \\
\text { is used as a diaphoretic and alone. it is good to regulate } \\
\text { blood pressure }\end{array}$ & PUR & $\mathrm{H}$ & 0.57 \\
\hline \multicolumn{6}{|l|}{ Amaranthaceae } \\
\hline $\begin{array}{l}\text { Alternanthera brasiliana (L.) Kuntze, } \\
\text { penicilina, anador }\end{array}$ & Leaf & The infusion is used as anti-inflammatory & $\mathrm{N}$ & $\mathrm{H}$ & 0.54 \\
\hline Gomphrena demissa Mart., capitão & Root & $\begin{array}{l}\text { Makes a grinded mass to give to babies who have } \\
\text { problems at the teething time. as too flu and diarrhea }\end{array}$ & $\mathrm{N}$ & $\mathrm{H}$ & 0.86 \\
\hline Gomphrena leucocephala Mart., erva-santa & $\begin{array}{l}\text { Whole } \\
\text { plant }\end{array}$ & $\begin{array}{l}\text { The infusion is used as anti-inflammatory. for bad } \\
\text { digestion and treatment of kidneys and liver. Its } \\
\text { poultice is used to cure boils }\end{array}$ & $\mathrm{N}$ & $\mathrm{H}$ & 1.14 \\
\hline \multicolumn{6}{|l|}{ Anacardiaceae } \\
\hline Anacardium occidentale L., cajueiro & Stem-bark & $\begin{array}{l}\text { The water of bark cashew tree's is used for cicatrization } \\
\text { and as anti-inflammatory }\end{array}$ & $\mathrm{N}, \mathrm{C}$ & $\mathrm{T}$ & 0.29 \\
\hline $\begin{array}{l}\text { Myracrodruon urundeuva (Engl.) Fr. All., } \\
\text { aroeira }\end{array}$ & Stem-bark & $\begin{array}{l}\text { Decoction and aroeira's water are very used as anti- } \\
\text { inflammatory. alone or mixed with stem bark of other } \\
\text { species }\end{array}$ & $\mathrm{N}$ & $\mathrm{T}$ & 0.71 \\
\hline \multicolumn{6}{|l|}{ Apiaceae } \\
\hline Pimpinella anisum L., erva doce & Fruit & The tea is used against the flu & PUR & $\mathrm{H}$ & 0.29 \\
\hline \multicolumn{6}{|l|}{ Arecaceae } \\
\hline Cocos nucifera $\mathrm{L}$., coqueiro & Oil & $\begin{array}{l}\text { Topical use of almond oil is used along with the } \\
\text { quince's powder for cicatrization }\end{array}$ & $\mathrm{C}$ & $\mathrm{T}$ & 0.29 \\
\hline \multicolumn{6}{|l|}{ Asteraceae } \\
\hline Acmella uliginosa (Sw.) Cass., agrião & Flower & $\begin{array}{l}\text { It is used in "lambedor" for the flu. Chew up the leaves } \\
\text { and swallow the juice for gastritis }\end{array}$ & $\mathrm{C}$ & $\mathrm{H}$ & 0.57 \\
\hline Egletes viscosa (L.) Less., macela & Fruit & $\begin{array}{l}\text { The tea or the "lambedor" are used for bad digestion } \\
\text { and treatment of kidneys and liver }\end{array}$ & PUR & $\mathrm{H}$ & 0.86 \\
\hline Pectis elongata Kunth, cumim-bravo & $\begin{array}{l}\text { Whole } \\
\text { plant }\end{array}$ & The tea is used against back pain & $\mathrm{N}$ & $\mathrm{H}$ & 0.29 \\
\hline \multicolumn{6}{|l|}{ Bombacaceae } \\
\hline $\begin{array}{l}\text { Pseudobombax marginatum (A. St.-Hil. } \\
\text { Juss.\& Cambess.) A. Robyns, imbiratanha }\end{array}$ & Stem-bark & $\begin{array}{l}\text { The water of bark of imbiratanha can be used as anti- } \\
\text { inflammatory, contraceptive, for ulcers and gastritis }\end{array}$ & $\mathrm{N}$ & $\mathrm{T}$ & 1.0 \\
\hline \multicolumn{6}{|l|}{ Burseraceae } \\
\hline $\begin{array}{l}\text { Commiphora leptophloeos (Mart.) J.B. } \\
\text { Gillett., imburana }\end{array}$ & Stem-bark & $\begin{array}{l}\text { The water of stem bark of imburana can be drunk during } \\
\text { the day. against gastritis. and it is also used in baths for } \\
\text { the cicatrization of cuts and wounds. It's "lambedor" is } \\
\text { indicated as anti-inflammatory and anticancer }\end{array}$ & $\mathrm{N}$ & $\mathrm{T}$ & 1.14 \\
\hline \multicolumn{6}{|l|}{ Bromeliaceae } \\
\hline Ananas comosus L., abacaxi & Fruit & $\begin{array}{l}\text { The "lambedor" is used for "sore throat". the flu and } \\
\text { start of pneumonia. }\end{array}$ & PUR & $\mathrm{H}$ & 0.57 \\
\hline \multicolumn{6}{|l|}{ Capparaceae } \\
\hline Cleome affinis DC., muçambê & Leaf & $\begin{array}{l}\text { The "melador" can be made mixed with other plants } \\
\text { against the flu }\end{array}$ & $\mathrm{C}$ & $\mathrm{H}$ & 0.29 \\
\hline \multicolumn{6}{|l|}{ Caricaceae } \\
\hline Carica papaya L., mamoeiro & Young leaf & $\begin{array}{l}\text { The infusion of the young leaves is used against } \\
\text { intestinal disorder }\end{array}$ & $\mathrm{C}$ & $\mathrm{T}$ & 0.29 \\
\hline \multicolumn{6}{|l|}{ Celastraceae } \\
\hline Maytenus rigida Mart., cabelo-de-negro & Leaf & $\begin{array}{l}\text { The "lambedor" can be made mixed with other plants } \\
\text { against bronchitis. }\end{array}$ & $\mathrm{N}$ & $\mathrm{S}$ & 0.29 \\
\hline \multicolumn{6}{|l|}{ Chenopodiaceae } \\
\hline Chenopodium ambrosioides L., mastruz & Leaf & $\begin{array}{l}\text { It is used mixed with milk for the treatment of bruises. } \\
\text { fractures. kidneys. lung problems and gastritis. }\end{array}$ & $\mathrm{C}$ & $\mathrm{H}$ & 1.29 \\
\hline
\end{tabular}




\section{Combretaceae}

Combretum leprosum Mart., mofumbo

Leaf

The "lambedor" of the stem bark can be used against bronchitis. the flu. cough

Convolvulaceae

Operculina macrocarpa (L.) Urb., batatade-purga

Crassulaceae

Bryophyllum pinata (Lam.) Oken, malvacorama, corama

Euphorbiaceae

Croton sonderianus Müll. Arg., marmeleiro

\section{Lamiaceae}

Hyptis suaveolens Poit., samba-coité

Mentha $x$ villosa Huds., hortelã

Mentha arvensis L., hortelã-mentol

Ocimum americanum L., manjerona

Ocimum gratissimum L., louro

Plectrantus amboinicus (Lour.) Spreng., malvarisco, malvariço

Plectranthus barbatus Andr., boldo

Leguminosae Caesalpinioideae

Bauhinia cheilantha (Bong.) Steud., mororó

Caesalpinia pyramidalis Tul., catingueira

Caesalpinia ferrea Mart., jucá

Tamarindus indica L., tamarindo

Leguminosae Mimosoideae

Anadenanthera colubrina (Vell.) Brenan, angico, angico-branco

\section{Leguminosae Papilionoideae}

Amburana cearensis (Allem.) A. C. Smith, cumaru

\section{Liliaceae}

Aloe vera L., babosa

Lythraceae

Punica granatum L., romã
Root Can be made as candy or grinded mass against worms and to thin blood

Leaf Topical use how anti-inflammatory against boils and wounds

Stem-bark It is used for healing. by putting coconut oil in the cut and then putting the dry powder of stem bark forming a crust

Young leaf The tea of the young leaves can be used against fever. bad digestion and headache

Leaf The tea or "melador" is used against headache. the flu and fever. Other herbs can me mixed in. The plant is used against "voodoo"

Leaf The tea or "melador" is used against headache. the flu and fever. Other herbs can me mixed in. The plant is used against "voodoo

Leaf The tea is used against bad digestion

Leaf The tea is used against bad digestion. fever and headache

Leaf The "melador" of malvariço. mixed with cumaru's skin. angico. quixabeira or alone. is used to treat the respiratory tract as an expectorant.

Leaf The tea is used against bad digestion

Leaf The tea is used for fighting diabetes and cholesterol

Flower The "melador" is used against coughs and colds

Flower The "lambedor" can be made of the flowers against the and fruit flu. and the maceration of the pod makes a powder. the powder is soaked and the water is used as a general anti-inflammatory and for ovarian inflammation. It is also used for gastritis and eye diseases

Leaf The tea is used as anti-inflammatory for toothache

Stem-bark The "melador" is used against the flu. Also used for cicatrization. anti-inflammatory and in "garrafadas" (bottled).

Stem-bark

The "lambedor" is used against fatigue. it is mixed with mint and mallow's leaves or used separately against respiratory illness. or mixed with other plants against bronchitis. For sinusitis. it the stem bark is soaked overnight for face washing the next day

Leaf The topical use of Aloe Vera's juice is good for healing and as anti-inflammatory.

Fruit rind. The "lambedor" can be used against the flu. sore throat seed and treatment of liver and kidneys diseases. It can also be soaked the fruit rind and drink the water.
$\mathrm{N} \quad \mathrm{S}$

0.43

$\mathrm{N}$

$\mathrm{H}$

0.57

C

$\mathrm{H}$

$\mathrm{N}$

S

N

$\mathrm{H}$

C $\mathrm{H}$

C

$\mathrm{H}$

C

$\mathrm{H}$

C $\mathrm{H}$

0.29

C

$\mathrm{H}$

$\mathrm{N}$

$\mathrm{S} \quad 0.43$

$\begin{array}{lll}\mathrm{N} & \mathrm{T} & 0.43\end{array}$

$\begin{array}{lll}\text { N.C } & \text { T } & 1.14\end{array}$

$\begin{array}{lll}\text { C } & \text { T } & 0.57\end{array}$

N $\quad \mathrm{T} \quad 0.86$

$\mathrm{N}$

$\mathrm{T}$

C $\quad$ H $\quad 0.35$

C T

1.14 


\begin{tabular}{|c|c|c|c|c|c|}
\hline \multicolumn{6}{|l|}{ Malpighiaceae } \\
\hline Malpighia emarginata DC., acerola & Fruit & $\begin{array}{l}\text { Acerola's juice with honey three times a day to cure } \\
\text { the flu }\end{array}$ & $\mathrm{C}$ & $\mathrm{T}$ & 0.29 \\
\hline \multicolumn{6}{|l|}{ Myrtaceae } \\
\hline Eucalyptus globulus Labill., eucalipto & Leaf & $\begin{array}{l}\text { The tea can be used as sudorific. mixed with garlic and } \\
\text { lemon }\end{array}$ & PUR & $\mathrm{T}$ & 0.29 \\
\hline Psidium guajava L., goiabeira & Young leaf & $\begin{array}{l}\text { The tea of young leaves of guava's tree is used against } \\
\text { stomachache and diarrhea }\end{array}$ & $\mathrm{C}$ & $\mathrm{T}$ & 0.29 \\
\hline \multicolumn{6}{|l|}{ Olacaceae } \\
\hline Ximenia americana $\mathrm{L}$. , ameixa & Stem-bark & $\begin{array}{l}\text { Decoction and aroeira's water are very used as anti- } \\
\text { inflammatory. alone or mixed with stem bark of other } \\
\text { species }\end{array}$ & $\mathrm{N}$ & $\mathrm{T}$ & 0.71 \\
\hline \multicolumn{6}{|l|}{ Phillanthaceae } \\
\hline $\begin{array}{l}\text { Philantus niruri L., quebra-pedra, pedra- } \\
\text { nas-costas }\end{array}$ & $\begin{array}{l}\text { Whole } \\
\text { plant }\end{array}$ & The tea is recommended to fight kidney stones & $\mathrm{N}$ & $\mathrm{H}$ & 0.29 \\
\hline \multicolumn{6}{|l|}{ Poaceae } \\
\hline Cymbopogon citratus Stapf, capim-santo & Leaf & Tea for stomach aches and soothing & $\mathrm{C}$ & $\mathrm{H}$ & 0.57 \\
\hline \multicolumn{6}{|l|}{ Rhamnaceae } \\
\hline Ziziphus joazeiro Mart., juazeiro & Stem-bark & Against flakes and expectorant & $\mathrm{N}$ & $\mathrm{T}$ & 0.57 \\
\hline \multicolumn{6}{|l|}{ Rubiaceae } \\
\hline Morinda citrifolia $\mathrm{L}$., noni & Fruit & Drink the juice against cancer & $\mathrm{C}$ & $\mathrm{T}$ & 0.29 \\
\hline \multicolumn{6}{|l|}{ Rutaceae } \\
\hline Citrus limon (L.) Burm. F., limão & $\begin{array}{l}\text { Fruit and } \\
\text { fruit rind }\end{array}$ & $\begin{array}{l}\text { Can be used as juice or with honey in the treatment of } \\
\text { the flu. The juice is also used against diarrhea }\end{array}$ & $\mathrm{C}$ & $\mathrm{T}$ & 0.71 \\
\hline Citrus aurantium L., laranjeira & $\begin{array}{l}\text { Fruit rind } \\
\text { and leaf }\end{array}$ & $\begin{array}{l}\text { It is used in addition in "garrafadas". It is used for the } \\
\text { flu and cold }\end{array}$ & $\mathrm{C}$ & $\mathrm{T}$ & 0.29 \\
\hline \multicolumn{6}{|l|}{ Sapotaceae } \\
\hline $\begin{array}{l}\text { Sideroxylon obtusifolium (Humb. ex Roem. } \\
\text { \& Schult.) T.D. Penn., quixabeira, quixabeira- } \\
\text { branca }\end{array}$ & Stem-bark & $\begin{array}{l}\text { The stem bark in used in decoction or even soaked. } \\
\text { mixed with other herbs or alone against the flu. bruises. } \\
\text { wounds. diabetes. infections. lump in the uterus. } \\
\text { anticancer. ovarian inflammation. and inflammation in } \\
\text { general }\end{array}$ & $\mathrm{N}$ & $\mathrm{T}$ & 2.0 \\
\hline \multicolumn{6}{|l|}{ Scrophulariaceae } \\
\hline Scoparia dulcis L., vassourinha & $\begin{array}{l}\text { Whole } \\
\text { plant }\end{array}$ & The tea is used as anti-inflammatory & $\mathrm{N}$ & $\mathrm{H}$ & 0.29 \\
\hline \multicolumn{6}{|l|}{ Turneraceae } \\
\hline Turnera subulata $\mathrm{Sm}$., chanana & $\begin{array}{l}\text { Leaf and } \\
\text { root }\end{array}$ & It is used to supplement the "garrafadas" & $\mathrm{C}$ & $\mathrm{H}$ & 0.29 \\
\hline \multicolumn{6}{|l|}{ Verbenaceae } \\
\hline $\begin{array}{l}\text { Lippia alba (Mill.) Brow., cidreira, erva- } \\
\text { cidreira }\end{array}$ & Leaf & $\begin{array}{l}\text { The tea is used against hypertension. stomach ache and } \\
\text { as soothing }\end{array}$ & $\mathrm{C}$ & S & 0.71 \\
\hline \multicolumn{6}{|l|}{ Violaceae } \\
\hline $\begin{array}{l}\text { Hybanthus calceolaria (L.) Oken, } \\
\text { papaconha }\end{array}$ & Root & $\begin{array}{l}\text { Makes a mass of roots to give the children for teething } \\
\text { and diarrhea }\end{array}$ & $\mathrm{N}$ & $\mathrm{H}$ & 0.57 \\
\hline
\end{tabular}

The specialists residents on the Sítio do Gois classified medicinal plants in two groups, the herbs and tree bark, the first group includes those plants that can be found in homegardens or purchased as $P$. amboinicus, $M$. arvensis, C. ambrosioides, E. globosa. The second group is those medicinal plants which are originated from the native vegetation as A. cearensis, C. ferrea, S. obtusifolium, M. urundeuva.

The population at the Sítio do Gois has a classification for quixabeira (Sideroxylum obtusifolium) and angico (Anadenanthera colubrina), they separate into different types, for example, there are: "quixabeira caraquenta" and "quixabeira-branca" for the angico, there are: "angico caraquento" and "angico-branco". The medicinal plant species are only those smooth-bark ("angico-branco", "quixabeira-branca", "quixabeiraviúva"). This classification is very important for pharmacological studies so they can be conducted to 
identify if there is such a distinction indeed.

It is common to observe the presence of native species in homegardens on the humid tropics and arid regions. However, there is one in every area of exotics (Albuquerque et al., 2005b). Research indicates that in many homegardens the presence of native plants associated with introduced species makes these areas similar to natural forest systems, a seemingly ecologically balanced environment (Guarim Neto \& Carniello 2008; Albuquerque et al., 2007). It was expected, however, find a greater diversity of native species due to its proximity to the fragment of caatinga, as seen by Albuquerque et al. (2005a) in the homegardens of the city of Alagoinha, semi-arid northeastern Brazil.

The most native species showed high relative importance (RI>1.0) i.e. they were the most cited species in the community. The species Sideroxylon obtusifolium $(\mathrm{RI}=2.0)$, Gomphrena leucocephala Mart. (RI=1.14), Chenopodium ambrosioides (RI=1.29), Comiphora leptophleos $(\mathrm{RI}=1.14)$, Caesalpinia ferrea $(\mathrm{RI}=1.14)$, Punica granatum (RI=1.14) and Pseudobombax marginatum ( $\mathrm{RI}=1.0)$ showed the highest values of Relative Importance.

These species show woody, shrubs and herbaceous growth habit, and the versatility does not appear to be associated with the growth habit, as tested Almeida \& Albuquerque (2002) in nine species of plants with great versatility of their uses, with an RI $>1$ being recommended for up to eight body systems. Pharmacological studies are needed with the native species with high RI quoted above because according to Albuquerque et al. (2007), from a pharmacological standpoint, the RI rate can be considered an important criterion for selection of plants for more detailed studies of their biological and pharmacological activities.

The quixabeira tree (S. obtusifolium) has a great importance within the Sítio do Gois as perceived by the maximum value of relative importance and the number of citations. In the interviews, it was noticed that it is pointed out as the most "medicinal" (versatile) of the plants, according to an informant "whatever you feel, drink quixabeira's water", it was indicated to cure the flu, bruises, wounds in the uterus, anticancer, ovarian inflammation and other inflammations in general. In Feira de Caruaru, Pernambuco, Almeida \& Albuquerque (2002) found that the quixabeira tree also had the highest relative importance, thus demonstrating a high versatility in their body systems. The use of the tree involves removing the stem bark, which most often affects the development of the plant and can cause death.

As for active body systems (Table 2) most of the quotes of the uses were for diseases of the digestive system $(22.9 \%)$ and respiratory system $(15.6 \%)$, as other studies conducted in Rio Grande do Norte and Northeastern Brazil (Roque et al. 2010; Silva \& Freire 2010; Albuquerque et al. 2007; Almeida \& Albuquerque 2002) also reported a greater number of citations for disorders of the digestive and respiratory systems.

Table 2. Body system, number and percentage of citations, Sítio do Gois, Apodi-RN.

\begin{tabular}{lcc}
\hline \multicolumn{1}{c}{ Body systems } & $\begin{array}{c}\text { Number of } \\
\text { citations }\end{array}$ & Percentage (\%) \\
\hline Diseases of the digestive system & 22 & 22.9 \\
Diseases of the respiratory system & 15 & 15.6 \\
Diseases of the genitourinary system & 12 & 12.5 \\
Diseases of the circulatory system & 2 & 2.1 \\
Diseases of the eyes and adnexa & 1 & 1.0 \\
Diseases of the nervous system & 2 & 2.1 \\
Infections and parasitic diseases & 4 & 4.2 \\
Diseases of the skin and & 11 & 11.5 \\
subcutaneous tissues & 4 & \\
Diseases of the musculoskeletal & & 4.2 \\
system and connective tissues & 3 & 3.1 \\
Diseases of the blood and blood- & & \\
forming organs & 3 & 3.1 \\
Neoplasias & 17 & 17.7 \\
Afflictions and pains not defined & & \\
\hline
\end{tabular}

All species cited by five or more informants showed Concordance Rate Use (CUP) more than 50\% (Table 3), which is considered high by Pinto et al. (2006). A. cearensis, the species most often cited, with the main use for sinusitis, and $70 \%$ of informants cited this therapeutic aim for the species. The other species most frequently mentioned (M. urundeuva, S. obtusifolium and $X$. americana) also had very high CUP (greater than $77 \%$ ), but when consider the value for the species most often cited (CUPc) it drops to $70 \%$.

Roque et al. (2010) studied the community of Laginhas, Caico, Rio Grande do Norte, observed values were very low to CUPc for S. obtusifolium and $X$. americana, 41.7 and $25 \%$, respectively. The value of CUPc is generally lower than the CUP, as it is on the plant with the highest number of citations. The species B. cheilantha, C. leptophloeos, P. marginatum, L. alba and $P$. granatum showed CUPc 30 to $40 \%$ indicating little agreement of respondents as to the principal use. Through the corrected popular use concordance (CUPc) are indicated uses more widespread and accepted to one species, therefore, they are probably used and recognized by many people, what indicates greater certainty as to its validity (Vendruscolo \& Mentz 2006).

Thus, the species with CUPc above 50\% may show a considerable potential for medical use, as with $67.8 \%$ species listed in Table 3 . So considering 
the various calculated indices it is confirmed and underlined the need for more studies to validate the use of native A. cearensis, M. urundeuva, S. obtusifolium and $X$. americana.

The index of Shannon-Wiener calculated was 2.59. This value is quite close to that found in Barcarena, Pará (2.14) by Amorozo (1997), in Itacaré, Bahia (1.83) by Pinto et al (2006) and the Vale da Ribeira, São Paulo (1.86) by Di Stasi et al (2002). In this study the sampling effort was concentrated on informants who had more knowledge about the use of medicinal species (specialists), and possibly for this reason the index of diversity of community was high.

The most frequently used plant parts at the Sítio do Góis were leaves (39.2\%) and stem bark $(21.6 \%)$ (Figure 1) unlike other studies conducted in the caatinga (Albuquerque \& Andrade, 2002b; Agra et al., 2007; Teixeira \& Melo, 2006; Franco \& Barros, 2006; Roque et al., 2010). This divergence of results may be explained by the presence at the Sítio do Gois of both native plants (barks removed) and cultivated (removal of leaves). Concerning the native plants (cultivated), according to Castellucci et al. (2000), leaves are more accessible and they are presented throughout the year, while in native plants barks are present all year which did not occur with the leaves, due to deciduous in the dry season Albuquerque \& Andrade, 2002a). According to Silva \& Freire (2010) study, performed in Seridó region, Rio Grande do Norte, it can be confirmed that in exotic species the leaves are more used, and in native species the bark.

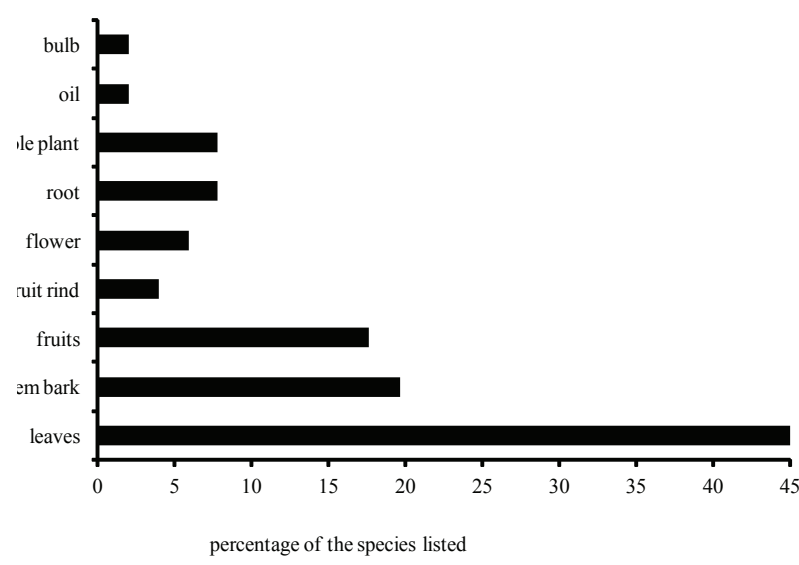

Figure 1. Percentage species listed and plant part used for medicinal purposes by the informants at the Sítio do Gois. Apodi-RN, 2010.

The most used method for the preparation of drugs was infusion (37.3\%), followed the mash (15.7\%), lambedor (15.7\%), and melador (13.7\%) (Figure 2). The tea can be made as infusion or decoction and there is much variation as to the meaning of the word "tea", depending on the person and according to the plant. Thus in Table 1 the word tea can mean infusion or decoction (29.4\%). In the expression "água de imburana", "água de aroeira", among others, the word water means that part of the plant was only soaked in water without boiling and in this study was classified as macerated.

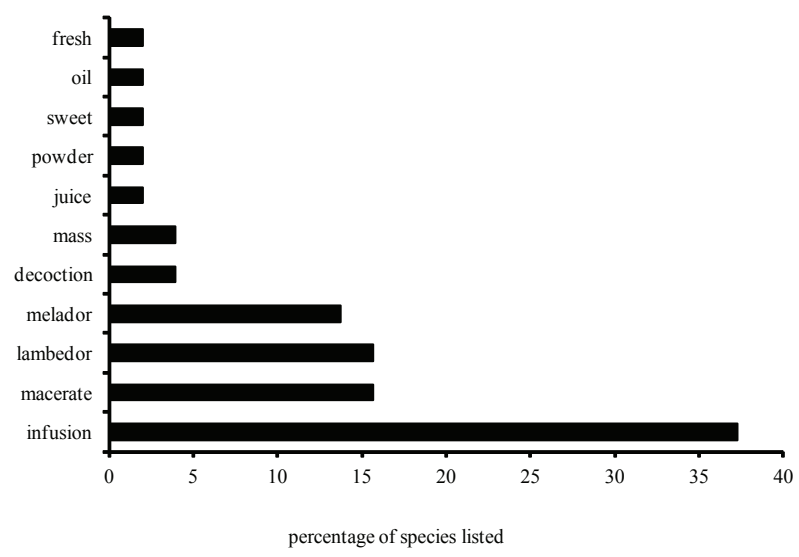

Figure 2. Percentage of species listed and use form of plants with medicinal purposes by the informants at the Sítio do Gois, Apodi-RN, in 2010.

The syrup is a method that uses a concentrated sugar solution to dissolve the phyto-complex of one or more plants (Oliveira \& Coelho, 2004). In the village of this study it was found that residents call the syrup, "lambedor", and also "melador". The word "lambedor" has common use in populations living in the caatinga of RN (Roque et al., 2010). However the name "melador" seems to be more common in the city of Apodi-RN, as Paulino et al. (2009) found that some academic students interviewed in the city of Apodi-RN also cited the syrup as "melador". Considering these facts, the preparations were the most commonly used teas and syrups, as verified by Mosca \& Loiola (2009), Arnous et al. (2005), Medeiros et al. (2004) and Amorozo (2002).

The embiratanha (Pseudobombax marginatum) presented a contraceptive activity not found in other surveys of its medicinal use in the Northeast (Agra et al., 2007; Albuquerque et al., 2007), only Oliveira (1976) has emphasized such use of $P$. marginatum by the population of Mossoró-RN. Interestingly in many ethno botanical surveys in the northeast Cominphora leptophloeos has always been showning medicinal properties, however, a review by Albuquerque et al. (2007) found no chemical and pharmacological studies on this species.

Some plants seem to have very similar use, such as wound healing and anti-inflammatory: imburana (Cominphora leptophloeos), quixabeirabranca (Sideroxylum obtusifolium), plum (Ximenia americana), aroeira (Myracrodruon urundeuva), jucá 
Table 3. Percentage of concordance on the principal use (five species mentioned by informants or more), Sítio do Gois, Apodi-RN, 2010.

\begin{tabular}{|c|c|c|c|c|c|c|}
\hline Scientific name of species & principal use & ICUE & ICUP & CUP & $\mathrm{Fc}$ & CUPc \\
\hline Amburana cearensis (Allemão) A. C. Sm. & sinusitis & 10 & 7 & 70.0 & 1.0 & 70 \\
\hline Anandenanthera colubrina (Vell.) Brenan & flu & 6 & 5 & 83.3 & 0.6 & 50 \\
\hline Bauhinia cheilantha (Bong.) Steud. & high cholesterol & 5 & 4 & 80.0 & 0.5 & 40 \\
\hline Caesalpinia ferrea Mart. & inflammation & 5 & 5 & 100.0 & 0.5 & 50 \\
\hline Chenopodium ambrosioides L. Huds. & fracture & 7 & 6 & 85.7 & 0.7 & 60 \\
\hline Citrus limon (L.) Burm. F. & flu & 7 & 6 & 85.7 & 0.7 & 60 \\
\hline Commiphora leptophloeos (Mart.) J.B. Gillett. & healing & 5 & 4 & 80.0 & 0.5 & 40 \\
\hline Cymbopogon citratus Stapf & soothing & 6 & 5 & 83.3 & 0.6 & 50 \\
\hline Lippia alba (Mill.) Brow. & belly ache & 8 & 4 & 50.0 & 0.8 & 40 \\
\hline Mentha $x$ villosa & headache & 7 & 5 & 71.4 & 0.7 & 50 \\
\hline Myracrodruan urundeuva Allemao & inflammation & 9 & 8 & 88.9 & 0.9 & 80 \\
\hline Plectrantus amboinicus (Lour.) Spreng. & flu & 9 & 9 & 100.0 & 0.9 & 90 \\
\hline Pseudobombax marginatum (A. St.-Hil.. Juss.\& Cambess.) A. Robyns & healing & 5 & 3 & 60.0 & 0.5 & 30 \\
\hline Punica granatum $\mathrm{L}$. & sore throat & 5 & 4 & 80.0 & 0.5 & 40 \\
\hline Sideroxylon obtusifolium (Humb. ex Roem. \& Schult.) T.D. Penn. & inflammation & 9 & 7 & 77.8 & 0.9 & 70 \\
\hline Ximenia americana $\mathrm{L}$. & healing & 9 & 7 & 77.8 & 0.9 & 70 \\
\hline
\end{tabular}

ICUE: number of informants citing use of the species; ICUP: number of informants citing primary use of species; CUP: concordance rate of use; Fc: correction factor; CUPc: concordance rate of use corrected $=\mathrm{CUP} \times \mathrm{Fc}$.

(Caesalpinia ferrea), cajueiro (Anacardium ocidentale), angico-branco (Anadenanthera colubrina), embiratanha (Pseudobombax marginatum) and all these involve remove stem bark.

This makes the technique of removing the stem bark quite aggressive to the plants, if concentrated in one species, rather than distributed among species. It can lead to its extinction at that location. Most of these plants already have studies that prove these properties mainly by the presence of tannins (Lorenzi \& Matos, 2008). Thus it is possible to make a sustainable management of material collection removing few barks from a greater amount of species.

\section{Conclusions}

Informants are aware of specific uses of native medicinal plants of the caatinga and homegardens, although it was registered a relatively small number of species in relation to other studies in northeastern Brazil. The most commonly used preparations are teas and syrups. Are used leaves and stem bark and great number of citations are for disorders of the digestive and respiratory systems. The most important species are $A$. cearensis, M. urundeuva, S. obtusifolium and $X$. americana and deserve further validation studies.

\section{Acknowledgment}

The authors thank the residents in Village Sítio do Gois for the welcome and information to CNPq by PIBIC scholarship to the first author and Productivity scholarship to the fourth author. We are also grateful to Aníbal de Souza Mascarenhas Filho for the language review.

\section{References}

Agra MF, Baracho GS, Silva NK, Basílio IJLD, Coelho VPM 2007. Medicinal and poisonous diversity of the flora of "Cariri Paraibano". J Ethnopharmacol 111: 383395.

Albertasse PD, Thomaz LD, Andrade MA 2010. Plantas medicinais e seus usos na comunidade da Barra do Jucu, Vila Velha, ES. Rev Bras Plant Med 12: 250260.

Albuquerque UP, Andrade LHC 2002a. Uso de recursos vegetais na caatinga: o caso do agreste do estado de Pernambuco, nordeste do Brasil. Interciencia 27: 336346.

Albuquerque UP, Andrade LHC 2002b. Conhecimento botânico tradicional e conservação em uma área de caatinga no estado de Pernambuco, nordeste do Brasil. Acta Bot Bras 16: 273-285.

Albuquerque UP, Andrade LHC, Silva ACO 2005a. Use of plant resources in a seasonal dry forest (northeastern Brasil). Acta Bot Bras 19: 27-38.

Albuquerque UP, Cavalcanti LH, Caballero J 2005b. Structure and floristics of homegardens in Northeastern Brazil. $J$ Arid Environ 62: 491-506. 
Albuquerque UP, Hanazaki N 2006. As pesquisas etnodirigidas na descoberta de novos fármacos de interesse médico e farmacêutico: fragilidades e perspectivas. Rev Bras Farmacogn 16: 678-689.

Albuquerque UP, Lucena RFP, Alencar NL 2008. Métodos e técnicas para coleta de dados etnobotânicos. In: Albuquerque UP, Lucena RFP, Cunha LVF (org.). Métodos e técnicas na pesquisa etnobotânica. 2. ed. Recife: NUPEEA, p. 48-50.

Albuquerque UP, Medeiros PM, Almeida ALS, Monteiro JM, Lins-Neto EMF, Melo JG, Santos JP 2007. Medicinal plants of the caatinga (semi-arid) vegetation of NE Brazil: A quantitative approach. J Ethnopharmacol 114: 325-354.

Albuquerque UP, Oliveira RF 2007. Is the use-impact on native caatinga species in Brazil reduced by the high species richness of medicinal plants. $J$ Ethnopharmacol 113: 156-170.

Almeida CFCBR, Albuquerque UP 2002. Uso e conservação de plantas e animais medicinais no estado de Pernambuco (Nordeste do Brasil): um estudo de caso. Interciência 27: 276-285.

Almeida NFL, Silva, SRS, Souza JM, Queiroz APN, Miranda GS, Oliveira HB 2009. Levantamento etnobotânico de plantas medicinais na cidade de Viçosa. MG. Rev Bras Farm 90: 316-320

Amorozo MCM 2002. Uso e diversidade de plantas medicinais em Santo Antonio do Leverger, MT, Brasil. Acta Bot Bras 16: 189-203.

Amorozo MCM, Gély AL 1988. Uso de plantas medicinais por caboclos do Baixo Amazonas. Bol Mus Para Emilio Goeldi 4: 47-131.

Amorozo MCMA 1996. Abordagem etnobotânica na pesquisa de plantas medicinais. In Di Stasi LC (Org). Plantas medicinais arte e ciência. Um guia de estudo interdisciplinar. São Paulo: Editora da Universidade Estadual Paulista, p.47-68.

Amorozo MCM 1997. Algumas notas adicionais sobre o emprego de plantas e outros produtos com fins terapêuticos pela população cabocla do Município de Barcarena, PA. Brasil. Bol Mus Para Emilio Goeldi 13: $192-213$

Arnous AH, Santos AS, Beinner RDC. 2005. Plantas Medicinais de uso caseiro - conhecimento popular e interesse por cultivo comunitário. Rev Espaço Saúde 6: 1-6.

Azevedo CMA 2005. A regulamentação do acesso aos recursos genéticos e aos conhecimentos tradicionais associados no Brasil. Biota Neotrop 5: 19-27.

Azevedo RAB, Coelho MFB 2002. Métodos de investigação do conhecimento popular sobre plantas medicinais. In Rodrigues, A.G. (Orgs.). Plantas medicinais $e$ aromáticas: etnoecologia e etnofarmacologia. Viçosa: UFV, p. 273-320.

Begossi A 1996. Use of ecological methods in ethnobotany:
Diversity Indices. Econ Bot 50: 280-289.

Bennett BC, Prance GT 2000. Introduced plants in the indigenous pharmacopoeia of Northern South America. Econ Bot 54: 90-102.

Bermúdez A, Oliveira-Miranda MA, Velásquez D 2005. La investigación etnobotânica sobre plantas medicinales: uma revision de sus objetivos e enfoques actuales. Interciencia 30: 453-459.

Carniello MA, Silva RS, Cruz MAB, Guarim Neto G 2010. Quintais urbanos de Mirassol D'Oeste-MT, Brasil: uma abordagem etnobotânica/Urban homegardens of Mirassol D'Oeste-MT, Brazil: an ethnobotany study. Acta Amaz 40: 451-470.

Castellucci S, Lima MIS, Nordi N, Marques JGW 2000. Plantas medicinais relatadas pela comunidade residente na estação ecológica de Jataí, município de Luis Antônio/SP: uma abordagem etnobotânica. Rev Bras Plant Med 3: 51-56.

Christo AG, Guedes-Bruni RR, Silva AG 2010. Conhecimento local em horta medicinal numa comunidade rural adjacente à Floresta Atlântica no sudeste do Brasil. Rev Bras Farmacogn 20: 494-501.

Dantas BL, Liberalino Filho J, Lira JFB, Maracajá PB, Diniz Filho ET 2007. A agroecologia nos assentamentos de: Moaci Lucena, Sítio do Góis e Vila Nova em ApodiRN. Infotecnarido 1: 1-12.

Di Stasi LC, Oliveira GP, Carvalhaes MA, Queiroz-Junior M, Tien OS, Kakinami SH, Reis MS 2002. Medicinal plants popularly used in the Brazilian Tropical Atlantic Forest. Fitoterapia 73: 69-91.

Duque-Brasil R, Soldati GT, Costa FV, Marcatti AA, Reis-Jr R, Coelho, FMG 2008. Riqueza de Plantas e Estrutura de Quintais Familiares no Semi-árido Norte Mineiro. Rev Bras Biociênc 5: 864-866.

Emperaire L, Pinton F 1986. Dona Flora et les cajous: deux systèmes agricoles au sud-est du Piauí (Brèsil). $J$ Agric Tradit Bot Appl 33: 193-212.

Florentino ATN, Araújo EL, Albuquerque UP 2007. Contribuição de quintais agroflorestais na conservação de plantas da Caatinga, Município de Caruaru, PE, Brasil. Acta Bot Bras 21: 37-47.

Fonseca IC, Liberalino Filho J, Dantas BL, Sizenando Filho FA, Nascimento F 2008 Assessoria técnica, social e ambiental em seis assentamentos de reforma agrária no município de Apodi-RN. Intesa 2: 10-14.

Franco EAP, Barros RFM 2006. Uso e diversificação de plantas medicinais no quilombo olho d'água dos Pires, Esperantina, Piauí. Rev Bras Plant Med 8: 78-88.

Governo do Rio Grande do Norte 2010. Instituto de Desenvolvimento Sustentável e Meio Ambiente do RN. Perfil do seu município. http://www.idema.rn.gov.br/ contentproducao/aplicacao/idema/socio_economicos/ arquivos/apodi/apodi.doc, acessed March 2010.

Guarim Neto G, Carniello MA 2008. Quintais matogrossenses: espaços de conservação e reprodução de 
saberes. EDUNEMAT: Cáceres.

Guerra AMNM, Pessoa MF, Souza CSM, Maracajá PB 2010. Utilização de plantas medicinais pela comunidade rural Moacir Lucena, Apodi-RN. Biosci J 26: 442450.

IUCN 2007a. IUCN Red List of Threatened Species. Astronium urundeuva. http//www.iucnredlist.org, acessed Nov 2007

IUCN 2007b. IUCN Red List of Threatened Species. Amburana cearensis. http//www.iucnredlist.org, acessed Nov 2007

Leal LKAM, Canuto KM, Costa KCS, Nobre-Júnior HV, Vasconcelos SM, Silveira ER, Ferreira MVP, Fontenele JB, Andrade GM, Viana GSB 2009. Effects of amburoside A and isokaempferide, polyphenols from Amburana cearensis, on rodent inflammatory processes and myeloperoxidase activity in human neutrophils. Basic Clin Pharmacol Toxicol 104: 198205.

Lorenzi H, Matos FJA 2008. Plantas medicinais no Brasil: nativas e exóticas, 2ed. Nova Odessa, SP, Instituto Plantarum.

Maciel MAM, Pinto AC, Veiga Jr VF, Grynberg NF, Echevarria A 2002. Plantas medicinais: A necessidade de estudos interdisciplinares. Quim Nova 25: 429-438.

Maikai VA, Kobo PI, Maikai BVO 2010. Antioxidant properties of Ximenia americana. African J Biotechnol 9: 77447746.

Medeiros MFT, Fonseca VS, Andreata RHP 2004. Plantas medicinais e seus usos pelos sitiantes da Reserva Rio das Pedras, Mangaratiba, RJ,Brasil. Acta Bot Bras 18: 391-399.

Ministério do Meio Ambiente 2008. Instrução normativa no. 6, de 23 de setembro de 2008. Reconhece espécies da flora ameaçadas de extinção. Diário Oficial da União no. 128, Brasilia-DF, 24 set 2008.

Ministério de Minas e Energia 2005. Projeto cadastro de fontes de abastecimento por água subterrânea: Rio Grande do Norte: diagnóstico do Município de Apodi. Serviço Geológico do Brasil, Secretaria de Geologia, Mineração e Transformação Mineral. Recife: CPRM, $10 \mathrm{p}$.

MoscaVP, Loiola MIB 2009. Uso popular de plantas medicinais no Rio Grande do Norte, nordeste do Brasil. Caatinga 22: 225-234.

Oliveira OF 1976. Algumas árvores do município de Mossoró. Caatinga 1: 7-17.

Oliveira AX, Coelho MFB 2004. Uso de plantas medicinais. Cuiabá: SENAR AR/MT.

Oliveira FCS, Barros RFM, Moita Neto JM 2010a. Plantas medicinais utilizadas em comunidades rurais de Oeiras, semiárido piauiense. Rev Bras Plant Med 12: 282-301.

Oliveira GL, Oliveira AFM, Andrade LHC 2010b. Plantas medicinais utilizadas na comunidade urbana de
Muribeca, Nordeste do Brasil. Acta Bot Bras 24: 571577.

Paulino RC, Coelho MFB, Maia SSS, Henriques GPSA 2009. Conhecimento e uso de plantas medicinais por estudantes da Universidade Federal Rural do SemiÁrido, Mossoró, Rio Grande do Norte, Brasil. In: IV Seminário de Iniciação Científica. Mossoró, Rio Grande do Norte.

Pessoa DLR, Cartágenes MSS 2010. Utilização de plantas medicinais por moradores de dois bairros na cidade de São Luís, Estado do Maranhão. Enciclopédia Biosfera 6: 1-9.

Pinto EPP, Amorozo MCM, Furlan A. 2006. Conhecimento popular sobre plantas medicinais em comunidades rurais de Mata Atlântica - Itacaré, BA, Brasil. Acta Bot Bras 20: 751-762.

Rodrigues GSO, Aroucha EM, Linhares PCF, Queiroz RF, Bezerra FN, Souza P.A, Souza AE 2007. Características químicas de frutos da quixabeira. Rev Bras Agroecologia 2: 1473-1476.

Roque AA, Rocha RM, Loiola MIB 2010. Uso e diversidade de plantas medicinais da caatinga na comunidade rural de Laginhas, município de Caicó, Rio Grande do Norte, (nordeste do Brasil). Rev Bras Plant Med 12: 31-42.

Silva TS, Freire EMX 2010. Abordagem etnobotânica sobre plantas medicinais citadas por populações do entorno de uma unidade de conservação da caatinga do Rio Grande do Norte, Brasil. Rev Bras Plant Med 12: 427435.

Souza SM, Aquino LC, Milach AC Jr, Bandeira MA, Nobre ME, Viana GS 2007. Antiinflammatory and antiulcer properties of tannins from Myracrodruon urundeuva Allemão (Anacardiaceae) in rodents. Phytother Res 21: 220-225.

Teixeira AS, Melo JIM 2006. Plantas medicinais utilizadas no município de Jupi, Pernambuco, Brasil. Iheringia 61: 5-11.

Vendruscolo GS, Mentz LA 2006. Levantamento etnobotânico das plantas utilizadas como medicinais por moradores do bairro Ponta Grossa, Porto Alegre, Rio Grande do Sul, Brasil. Iheringia 61: 83-103,

WHO 2000. Organização Mundial da Saúde, CID-10: Classificação Estatística Internacional de Doenças e Problemas Relacionados à Saúde. São Paulo, Editora da Universidade de São Paulo.

\section{*Correspondence}

Maria de Fatima B. Coelho

Setor de Desenvolvimento Rural, Universidade da Integração Internacional da Lusofonia Afro Brasileira

Av. da Abolição, 7, Centro, 62790-000 Redenção-CE, Brazil coelhomf@pq.cnpq.br

Tel: +558533321568 